\title{
PENERAPAN PEMBELAJARAN CTL BERBANTUAN LKPD TERHADAP KEMAMPUAN PEMAHAMAN KONSEP DAN PEMECAHAN MASALAH SISWA
}

\author{
Nining Choiriyanisa ${ }^{1}$, Dewi Azizah², Syita Fatih'adna ${ }^{3}$ \\ 1,2,3 Universitas Pekalongan \\ e-mail: ${ }^{1}$ choiriyanisa.nienk@gmail.com, 2azizah.0186@gmail.com, \\ 3syita.fatih@gmail.com
}

\begin{abstract}
ABSTRAK
Proses pembelajaran yang efektif merupakan salah satu unsur untuk mencapai tujuan keberhasilan dalam pembelajaran. Guru di SMK Gondang sudah mengupayakan variasi dalam mengajar sesuai kurikulum yang diterapkan yaitu dengan menerapkan pembelajaran PBL. Namun, penerapannya belum maksimal. Siswa merasa kesulitan dalam menyelesaikan permasalahan matematika jika tidak ada penjelasan materi terlebih dahulu. Padahal langkah awal dalam penerapan PBL yaitu siswa diberikan permasalahan terlebih dahulu untuk mengembangkan kemampuan berpikirnya. Oleh karena itu, diperlukan pembelajaran yang dapat mengembangkan kemampuan berpikir siswa baik kemampuan pemahaman konsep maupun kemampuan pemecahan masalah yaitu dengan pembelajaran CTL. Penelitian ini bertujuan untuk mengetahui apakah terdapat perbedaan kemampuan pemahaman konsep dan kemampuan pemecahan masalah siswa yang diajarkan menggunakan pembelajaran CTL berbantuan LKPD dengan pembelajaran PBL. Penelitian ini merupakan jenis penelitian eksperimen semu.Populasi dalam penelitian ini adalah seluruh siswa kelas XI SMK Gondang Wonopringgo. Instrumen penelitian yang digunakan berupa tes kemampuan pemahaman konsep dan pemecahan masalah siswa. Analasis data pada penelitian ini menggunakanuji beda rerata multivariate. Hasil penelitian ini diperoleh bahwa $H_{0}$ ditolak sehingga menunjukkan bahwa terdapat perbedaan kemampuan pemahaman konsep dan pemecahan masalah siswa baik dengan penerapan pembelajaran CTL maupun pembelajaran PBL.
\end{abstract}

Kata kunci: CTL, LKPD, Pemahaman konsep, Pemecahan Masalah.

\section{PENDAHULUAN}

Menurut Sujono (dalam Fathani, 2009) matematika merupakan ilmu pengetahuan tentang penalaran yang logik dan masalah yang berhubungan dengan bilangan.Matematika sebagai cabang ilmu pengetahuan yang eksak dan terorganisasi secara sistematik. Matematika juga sebagai ilmu bantu dalam menginterpretasikan berbagai ide dan kesimpulan. Melalui pembelajaran matematika, guru dapat mengenali karakteritik dan potensi siswa. Begitu juga dengan siswa dapat mengembangkan potensi yang dimilikinya. 
Berdasarkan hasil observasi dan wawancara dengan salah satu guru matematikadi SMK Gondang Wonopringgo, guru sudah menggunakan pembelajaran PBL. Namun pada pelaksanaanya belum maksimal. Siswa seringkali kesulitan dalam memecahkan persoalan matematika tanpa adanya penjelasan materi terlebih dahulu oleh guru. Padahal langkah awal pada pembelajaran PBL, guru memberikan permasalahan matematika kepada siswa. Tujuan pelaksanaan PBL ini untuk merangsang siswa berpikir mengkonstruksikan sendiri pengetahuannya sehingga terbentuk pengetahuan baru dari pemahaman siswa. Ini salah satu upya untuk mengembangkan potensi berpikir siswa. Namun, jika langkah tersebut belum dapat terlaksana dengan baik, maka pembelajaran selanjutnya akan terhambat.

Informasi dari salah satu guru di SMK tersebut juga menunjukkan bahwa kemampuan pemahaman konsep dan kemampuan pemecahan masalah siswa masih rendah. Rendahnya kemampuan pemahaman konsep dan pemecahan masalah siswa terlihat dari hasil pekerjaan siswa pada ulangan tengah semester. Hasil yang diperoleh siswa dalam menjawab permasalahan matematika terkait pemahaman konsep dan pemecahan masalah menunjukkan hasil yang kurang memuaskan. Sebagian siswa masih belum mampu menyatakan ulang konsep dan mengaplikasikan konsep kedalam soal. Selain itu, siswa juga masih banyak yang kesulitan dalam memecahkan masalah apabila siswa disajikan soal-soal non rutin yang memerlukan pemahaman lebih dalam menyelesaikannya.

Konsep-konsep dalam matematika mempunyai keterkaitan antara materi satu dengan materi lainnya. Hal ini bertujuan agar siswa mampu memahami konsep matematika secara mendalam. Pentingnya pemahaman konsep terlihat dalam tujuan pertama pembelajaran matematika menurut Depdiknas (Permendiknas no. 22 tahun 2006) yaitu memahami konsep matematika, menjelaskan keterkaitan antar konsep dan mengaplikasikan konsep secara luwes, akurat, efisien dan tepat dalam pemecahan masalah.

Widyastuti (2015) menyatakan bahwa kemampuan pemahaman konsep matematika adalah salah satu tujuan penting dalam pembelajaran. Kilpatrik (dalam Lestari dan Yudhanegara, 2015) menyatakan indikator pemahaman konsep matematis 
yaitu: (1) menyatakan ulang konsep; (2) mengklasifikasikan objek-objek berdasarkan konsep matematika; (3) menerapkan konsep secara algoritma; (4) memberikan contoh dan kontra contoh dari konsep yang dipelajari; (5) menyajikan konsep dalam berbagai representasi dan (6) mengaitkan berbagai konsep matematika secara internal dan eksternal.

Selain memahami konsep, tujuan pembelajaran matematika menurut Depdiknas (Permendiknas no. 22 tahun 2006) adalah pentingnya pemecahan masalah yang meliputi kemampuan memahami masalah, merancang model matematika, menyelesaikan model dan menafsirkan solusi yang diperoleh. Menurut Funke; 2001 (dalam Mauke, dkk., 2013) pada awal 1990-an, pemecahan masalah dipandang sebagai aktivitas yang bersifat mekanistis, sistematis, dan sering diasosiasikan dengan suatu konsep abstrak. Berdasarkan tujuan pembelajaran matematika tersebut diharapkan siswa memiliki kemampuan pemecahan masalah yang tinggi. Namun pada kenyataannya siswa masih banyak yang bingung apabila disajikan soal-soal non rutin yang perlu pemahaman yang lebih dalam menyelesaikan masalah tersebut.

Pencapaian tujuan pembelajaran matematika bukanlah suatu hal yang mudah. Fakta yang terjadi guru masih sulit untuk menanamkan suatu konsep pada siswa, sehingga siswa masih banyak yang belum dapat menyelesaikan masalah secara cepat, tepat, dan benar. Adanya kurikulum 2013 dengan pembelajaran yang berpusat pada siswa (student center) bukan lagi pada guru (teacher center) dapat menciptakan suasana yang berbeda dan berkesan sehingga pembelajaran yang berlangsung lebih bermakna.

Salah satu upaya yang dilakukan untuk menumbuhkan kemampuan pemahaman konsep dan pemecahan masalah siswa yaitu dengan menerapkan model pembelajaran Contextual Teaching and Learning (CTL). Menurut Johnson (2014) CTL adalah sebuah sistem yang merangsang otak untuk menyusun pola-pola yang mewujudkan makna. CTL merupakan suatu sistem pengajaran yang cocok dengan otak karena menghasilkan makna dengan menghubungkan muatan akademis dengan konteks kehidupan seharihari siswa. Delapan tahapan dalam pembelajaran CTL yaitu: (1) grouping (siswa berkelompok); (2) modeling (pemodelan); (3) questioning (bertanya); (4) learning 
community (masyarakat belajar); (5) inquiry (penemuan); (6) contructivism (membangun pemahan sendiri); (7) authentic assessment (penilaian) dan (8) reflection (refleksi proses pembelajaran).

Guna mendukung penerapan pembelajaran CTL, maka diperlukan bahan ajar yang sesuai dengan kebutuhan siswa. Salah satu bahan ajar yang dapat digunakan adalah LKPD. Pada LKPD tersebut dilengkapi dengan adanya kartu belajar. Kartu berisi langkah-langkah atau prosedur yang digunakan untuk membantu siswa menyelesaikan permasalahan yang ada pada LKPD. Tujuan penggunaan kartu ini adalah untuk melatih keterampilan pemahaman dan pemecahan masalah matematis pada siswa. Rumusan masalah pada penelitian ini yaitu: "apakah terdapat perbedaan kemampuan pemahaman konsep dan pemecahan masalah matematika siswa yang diajarkan menggunakan pembelajaran CTL berbantuan LKPD dengan PBL?".

\section{METODE PENELITIAN}

Metode yang digunakan dalam penelitian ini adalah eksperimen semu. Desaineksperimenyang digunakan pada penelitian ini adalah the nonequivalent pretest-posttest control group design. Populasi dalam penelitian ini adalah siswa kelas XI SMK Gondang Wonopringgo tahun pelajaran 2018/2019. Teknik pengambilan sampel dengan cara cluster random sampling. Sampel yang terpilih dua kelas yaitu kelas XI TKJ 2 sebagai kelas eksperimen yang menggunakan pembelajaran CTL dengan LKPD berbantuan kartu dan kelas XI TKJ 1 sebagai kelas kontrol yang menggunakan pembelajaran PBL. Data dalam penelitian ini diperoleh dengan metode tes. Metode tes digunakan untuk memperoleh data kemampuan pemahaman konsep dan kemampuan pemecahan masalah kelas eksperimen maupun kelas kontrol.

Data yang diperoleh saat penelitian kemudian dianalisis untuk menguji hipotesis. Teknik analisis yang digunakan adalah uji beda rerata multivariate untuk mengetahui ada atau tidaknya perbedaan kemampuan pemahaman konsep dan pemecahan masalah siswa pada kelas eksperimen dan kelas kontrol. Sebelum dilakukan uji hipotesis ada uji prasyarat yang harus terpenuhi, yaitu uji normalitas dan uji 
homogenitas. Jika hipotesis terbukti terdapat perbedaan maka dilakukan uji lanjut univariat pada masing-masing variabel terikat.

\section{HASIL PENELITIAN DAN PEMBAHASAN}

Berdasarkan hasil analisis data awal nilai pretest diperoleh bahwa data awal kelas eksperimen dan kelas kontrol berdistribusi normal, mempunyai matriks variansi dan kovariansi yang homogen dan tidak terdapat perbedaan kemampuan awal kedua kelas sampel. Sehingga dapat disimpulkan sampel berasal dari kondisi awal yang sama. Sedangkan hasil analisis akhir kelas eksperimen dan kelas kontrol berdistribusi normal dan mempunyai matriks variansi dan kovariansi yang homogen.

Hasil pengujian hipotesis dilakukan dengan uji beda rerata multivariate (uji-F). Berdasarkan uji-F diperoleh $F_{\text {obs }}=9,8201$, dengan taraf signifikan=0,05 diperoleh $F_{\text {tabel }}=3,26$. Sehingga $F_{\text {obs }}>F_{\text {tabel }}$ maka $H_{0}$ ditolak. Artinya, secara multivariat kemampuan pemahaman konsep dan pemecahan masalah siswa kelas eksperimen dan kelas kontrol tidak sama. Hasil penelitian ini sesuai dengan penelitian yang dilakukan oleh Mauke, dkk., (2013), menyatakan bahwa ada perbedaan yang signifikan pada kemampuan pemahaman konsep dan pemecahan masalah siswa yang diajar menggunakan model pembelajaran CTL dibandingkan dengan model pembelajaran konvensional. Karena $H_{0}$ ditolak maka dilakukan uji lanjut univariat pada masingmasing variabel terikat. Uji tersebut dilakukan untuk melihat dimana letak perbedaan kemampuan matematika pada kelas eksperimen dan kelas kontrol.

Uji lanjut untuk kemampuan pemahaman konsep menggunakan uji-t. Berdasarkan uji-t diperoleh $t_{o b s}=4,4015$, dengan taraf signifikan= 0,05 diperoleh $t_{\text {tabel }}=2,026$. Sehingga, $t_{\text {obs }}>t_{\text {tabel }}$ maka $H_{0}$ ditolak. Artinya, secara univariat kemampuan pemahaman konsep siswa pada kelas eksperimen dan kelas kontrol tidak sama.Rata-rata kemampuan pemahaman konsep siswa kelas eksperimen sebesar 76,18, sedangkan kemampuan pemahaman konsep siswa kelas kontrol sebesar 59,24. Jadi, nilai rata-rata kelas eksperimen lebih tinggi dibandingkan dengan kelas kontrol. Hasil analisis inidapat disimpulkan bahwa kemampuan pemahaman konsep siswa yang diajar menggunakan model pembelajaran CTL dengan LKPD berbantuan kartu lebih 
baik daripada kemampuan pemahaman konsep siswa yang diajar menggunakan model pembelajaran PBL. Hasil penelitian ini sesuai dengan penelitian yang dilakukan Hakim (2013), menyatakan bahwa kemampuan pemahaman konsep siswa yang diajar dengan model pembelajaran Contextual Teaching and Learning lebih baik daripada model pembelajaran langsung.

Uji lanjut untuk kemampuan pemecahan masalah menggunakan uji-t. Berdasarkan uji-t diperoleh $t_{o b s}=4,6384$, dengan taraf signifikan= 0,05 diperoleh $t_{\text {tabel }}=2,026$. Sehingga, $t_{\text {obs }}>t_{\text {tabel }}$ maka $H_{0}$ ditolak. Artinya, secara univariat kemampuan pemecahan masalah siswa pada kelas eksperimen dan kelas kontrol tidak sama. Rata-rata kemampuan pemecahan masalah siswa kelas eksperimen sebesar 72,45, sedangkan kemampuan pemahaman konsep siswa kelas kontrol sebesar 55,24. Jadi, nilai rata-rata kemampuan pemecahan masalah siswa kelas eksperimen lebih tinggi dibandingkan dengan kelas kontrol. Hasil analisis inidapat disimpulkan bahwa kemampuan pemecahan masalah siswa yang diajar menggunakan model pembelajaran CTL dengan LKPD berbantuan kartu lebih baik daripada kemampuan pemecahan masalah yang diajar menggunakan model pembelajaran PBL. Hasil penelitian ini sesuai dengan penelitian yang dilakukan Rusyida, dkk., (2013), yang menyatakan bahwa ratarata kemampuan pemecahan masalah siswa dalam pembelajaran dengan menggunakan model pembelajaran CTL lebih baik dibandingkan dengan rata-rata kemampuan pemecahan masalah siswa dalam pembelajaran dengan menggunakan model pembelajaran MEA.

Selama proses pembelajaran pada kelas eksperimen terlihat semakin membaik dari setiap pertemuan. Ketika pertemuan pertama keaktifan siswa belum terlihat, namun pada pertemuan selanjutnya siswa mulai terlihat aktif menggunakan kartu penyelesaian masalah untuk mrnyelesaikan permasalahan yang ada pada LKPD. Siswa juga antusias mencari tahu tentang hal-hal yang belum diketahui. Model pembelajaran CTL dengan LKPD berbantuan kartu penyelesaian masalah membuat siswa lebih aktif dalam pembelajaran. Siswa dituntut untuk menemukan konsep sendiri dari masalah yang diberikan oleh guru, sehingga siswa akan lebih lama dalam mengingat materi yang sudah dipelajarinya. Hal tersebut sesuai dengan teori belajar kontruktivistik 
(Budiningsih, 2012), menyatakan bahwa siswa harus benar-benar memahami dan dapat menerapkan pengetahuan, bekerja memecahkan masalah, menemukan segala sesuatunya untuk dirinya, dan berusaha memanfaatkan ide-ide. Sesuai dengan tahapan model pembelajaran CTL yaitu tahap contructivism. Pada tahap ini guru memberikan masalah yang berkaitan dengan materi dan mengajak siswa untuk mengidentifikasi masalah agar pemahaman siswa terhadap materi terbangun dengan sendirinya.

Pada tahap inquiry, dimana siswa disajikan LKPD dan kartu penyelesaian yang bertujuan untuk membangun pemahaman siswa melalui penemuan. Sehingga, memudahkan siswa dalam mengaitkan pengetahuan baru yang diperoleh dengan pengetahuan lama yang relevan. Hal tersebut sesuai dengan teori belajar Ausbel (Lestari dan Yudhanegara, 2015), menyatakan bahwa belajar seharusnya merupakan asimilasi yang bermakna bagi siswa. Selain itu pada tahap modeling, dimana siswa diberikan kesempatan untuk mengerjakan LKPD dengan bantuan kartu penyelesaian dalam diskusi bersama teman dalam kelompok. Hal tersebut sesuai dengan teori Bruner (Budiningsih, 2012), menyatakan bahwa pentingnya guru memberikan kesempatan kepada siswa untuk mempresentasikan model atau bagaimana cara mengerjakan secara lisan, tulisan atau dengan bentuk gambar. Berdasarkan hal tersebut, secara tidak langsung dapat membangun pemahamannya terhadap materi pelajaran dan melatih keterampilan pemecahan masalah siswa secara bertahap. Oleh karena itu berdasarkan hasil penelitian yang telah dilakukan kemampuan pemahaman konsep dan pemecahan masalah dengan menerapkan pembelajaran CTL berbantuan LKPD lebih baik daripada pembelajaran PBL.

\section{KESIMPULAN}

Berdasarkan hasil penelitian yang diperoleh dapat disimpulkan bahwa dari hasil analisis multivariat terdapat perbedaan kemampuan pemahaman konsep dan pemecahan masalah siswa yang diajar menggunakan model pembelajaran CTL dengan LKPD berbantuan kartu dengan model pembelajaran PBL. Dilakukan analisis uji lanjut univariat pada variabel terikat dan hasilnya adalah (1) Kemampuan pemahaman 
konsep siswa yang diajarkan menggunakan model pembelajaran CTL dengan LKPD berbantuan kartu lebih baik daripada kemampuan pemahaman konsep yang diajarkan menggunakan model pembelajaran PBL, dan (2) Kemampuan pemecahan masalah siswa yang diajarkan menggunakan model pembelajaran CTL dengan LKPD berbantuan kartu lebih baik daripada kemampuan pemecahan masalah yang diajar menggunakan model pembelajaran PBL.

\section{SARAN}

Berdasarkan hasil penelitian yang diperoleh, bagi guru penerapan pembelajaran CTL dapat dijadikan sebagai salah satu alternatif dalam meningkatkan kemampuan pemahaman konsep dan pemecahan masalah siswa. Penerapan pembelajaran CTL juga dapat diterapkan untuk mengembangkan kemampuan kognitif siswa lainnya seperti kemampuan penalaran, kemampuan komunikasi matematis, dan lain-lain.

\section{DAFTAR PUSTAKA}

Budiningsih, Asri. 2012. Belajar dan Pembelajaran. Jakarta: Rineka Cipta.

Budiyono. 2015. Pengantar Metode Statistika Multivariat. Surakarta: UPT UNS Press.

Depdiknas. 2006. Permendiknas No. 22 Tahun 2006 Tentang Standar Isi. Jakarta: Depdiknas.

Fathani, Abdul Halim. 2009. Matematika Hakikat dan Logika. Jogjakarta: Ar-Ruzz Media Group.

Hakim, Saiful. 2013. Penerapan Contextual Teaching dan Learning (CTL) dengan Media Powerpoint terhadap Pemahaman Konsep Segitiga Siswa Kelas VII MTs Muhammadiyah Pekajangan. Universitas Pekalongan: Tidak diterbitkan.

Jhonson, Elaine B. 2014. CTL Contextual Teaching \& Learning. Bandung: Kaifa.

Lestari, Karunia Eka dan Mokhammad Ridwan Yudhanegara. 2015. Penelitian Pendidikan Matematika. Bandung: PT Refika Aditama.

Mauke, Misrun, I Wayan Sadia, dan I Wayan Suastra. 2013. "Pengaruh Model Contextual Teaching and Learning terhadap Pemahaman Konsep dan Kemampuan Pemecahan Masalah dalam Pembelajaran IPA-Fisika di MTs Negeri Negara."e-Journal Program Pasca Sarjana Universitas Pendidikan Ganesha, 3.

Rusyida, Wilda Yulia, Mohammad Asikin, dan Edy Soedjoko. 2013. "Komparasi Model Pembelajaran CTL dan MEA terhadap Pemecahan Masalah Materi Lingkaran"Unnes Journal of Mathematics Education, 2 (1), 1-7. 
Widyastuti, E. 2015. "Peningkatan Kemampuan Pemahaman Konsep dan Komunikasi Matematis Siswa Menggunakan Pembelajaran Kooperatif Jigsaw."Journal Mathematics Education, 1 (1), 50-64. 